\title{
The production of intrinsically labeled milk protein provides a functional tool for human nutrition research ${ }^{1}$
}

\author{
L. J. C. van Loon, ${ }^{*} \dagger^{2}$ Y. Boirie, $\ddagger$ A. P. Gijsen,§ J. Fauquant,\#\| A. L. de Roos,ף A. K. Kies,ף S. Lemosquet, ${ }^{* *}+\dagger$ \\ W. H. M. Saris,§ and R. Koopman* \\ *Department of Human Movement Sciences, Nutrition and Toxicology Research Institute Maastricht (NUTRIM), Maastricht University, Maastricht, \\ the Netherlands \\ †Top Institute Food \& Nutrition, Wageningen, the Netherlands \\ łHuman Nutrition Unit, Université Clermont Auvergne, Centre de Recherche en Nutrition Humaine BP 321, 63009 Clermont-Ferrand Cedex 1, \\ France \\ §Department of Human Biology, NUTRIM, Maastricht University, Maastricht, the Netherlands \\ \#INRA, UMR1253, F-35042 Rennes Cedex, France \\ Agrocampus Ouest, UMR1253, F-35042 Rennes Cedex, France \\ IDSM Food Specialties, R\&D, Biochemistry and Nutrition Department, Delft, the Netherlands \\ ${ }_{* *}$ INRA, UMR1080 Dairy Production, F-35590 Saint-Filles, France \\ ††Agrocampus Ouest, UMR1080 Dairy Production, F-35000 Rennes, France
}

\begin{abstract}
Oral or intravenous administration of labeled, free amino acids does not allow the direct assessment of protein digestion and absorption kinetics following dietary protein intake. Consequently, dietary protein sources with labeled amino acids incorporated within the protein are required. The aim of this study was to produce milk proteins intrinsically labeled with $\mathrm{L}-\left[1-{ }^{13} \mathrm{C}\right]$ phenylalanine that would allow the assessment of protein digestion and absorption kinetics and the subsequent muscle protein synthetic response to dietary protein intake in vivo in humans. Two Holstein cows (body weight of $726 \pm 38 \mathrm{~kg}$ ) were continuously infused with L- $\left[1-{ }^{13} \mathrm{C}\right]$ phenylalanine at $402 \mu \mathrm{mol} / \mathrm{min}$ for 44 to $48 \mathrm{~h}$, during and after which plasma samples and milk were collected. After milk protein separation, casein was used in a subsequent human proof-of-principle experiment. Two healthy males (aged $61 \pm 1 \mathrm{yr}$; body mass index of $22.4 \pm 0.1 \mathrm{~kg} / \mathrm{m}^{2}$ ) ingested $35 \mathrm{~g}$ of casein highly enriched with $\left[1-{ }^{13} \mathrm{C}\right]$ phenylalanine. Plasma samples were collected at regular intervals, and skeletal muscle biopsies were collected before and $6 \mathrm{~h}$ after casein ingestion. In the initial experiment, a total of $5.83 \mathrm{~kg}$ of L- $\left[1-{ }^{13} \mathrm{C}\right]$ phenylalanine-enriched milk protein (casein enrichment was 29.4 molar percent excess) was collected during stable isotope infusion in the cows. In the proof-of-principle study, ingestion of $35 \mathrm{~g}$ of intrinsically labeled casein resulted in peak plasma $\mathrm{L}-\left[1-{ }^{13} \mathrm{C}\right]$ phenylalanine enrichments within 90 min after protein
\end{abstract}

\footnotetext{
Received April 22, 2009.

Accepted June 17, 2009.

${ }^{1}$ Supported by a grant from DSM Food Specialties, Delft, the Netherlands.

${ }^{2}$ Corresponding author: L.vanLoon@hb.unimaas.nl
}

ingestion (9.75 \pm 1.47 molar percent excess). Skeletal muscle protein synthesis rates calculated over the entire 6 -h period averaged $0.058 \pm 0.012 \% / \mathrm{h}$. The production of intrinsically labeled milk protein is feasible and provides dietary protein that can be used to investigate protein digestion and absorption and the subsequent muscle protein synthetic response in vivo in humans.

Key words: milk synthesis, dietary protein, digestion and absorption, muscle protein synthesis

\section{INTRODUCTION}

Food intake promotes net muscle protein accretion by providing ample AA as precursors for protein assembly (Wolfe, 2002). However, ingested AA and proteins should not be regarded merely as building blocks for de novo protein synthesis (Floyd et al., 1966) as they can also stimulate the release of anabolic hormones (van Loon et al., 2000, 2003; Koopman et al., 2005). Furthermore, a growing body of evidence indicates that AA can function as potent nutritional signaling molecules, playing an active role in regulating skeletal muscle protein metabolism (Kimball et al., 2002). It is believed that all essential amino acids are at least partly responsible for the AA-induced stimulation of muscle protein synthesis (Volpi et al., 2003). Their presence stimulates skeletal muscle protein synthesis by stimulating multiple steps in the mRNA translation process (Proud, 2004).

The quantity and quality of the ingested protein (i.e., its digestibility and AA composition) represent important factors that modulate the skeletal muscle anabolic response to dietary protein ingestion (Dangin et al., 2001). It has been speculated that a higher dietary protein digestion and absorption rate in the intestine will lead to a more rapid increase in plasma AA availability, thereby stimulating net muscle protein accretion 
(Dangin et al., 2003; Calbet and Holst, 2004). However, scientific evidence to support the proposed differences in the postprandial muscle protein synthetic response to the ingestion of either fast or slow digestible protein sources is lacking. The latter is largely because of the restrictions set by the methodology used to assess the appearance rate of AA from the gut into the circulation and the subsequent muscle protein synthetic response (Dangin et al., 2002). In general, intravenous administration of labeled leucine or phenylalanine has been applied to assess the effect of exogenous AA provision on bioavailability and their subsequent incorporation rate in skeletal muscle tissue (Wagenmakers, 1999).

As dietary free AA and protein-derived AA exhibit entirely different timing and efficiency of intestinal absorption (Boirie et al., 1996), simply adding labeled free AA to a protein-containing drink or meal does not provide a valid methodology to assess the digestion and absorption kinetics of dietary protein (Boirie et al., 1996, 1997a,b). To directly measure the appearance rate of AA derived from the digestion and absorption of dietary protein, the labeled AA must be incorporated within the dietary protein source. Therefore, intrinsically labeled dietary proteins are needed to study the effect of different dietary protein sources and feeding regimens on the subsequent digestion and absorption kinetics in vivo in humans.

The present study was performed to define an effective procedure to produce milk proteins intrinsically labeled with L- $\left[1-{ }^{13} \mathrm{C}\right]$ phenylalanine that would allow assessment of protein digestion and absorption kinetics and the subsequent muscle protein synthetic response to dietary protein intake in vivo in humans. Therefore, milk was collected from 2 cows being infused with up to $400 \mathrm{~g}$ of $\mathrm{L}-\left[1-{ }^{13} \mathrm{C}\right]$ phenylalanine. Milk proteins were extracted and applied in a human intervention study in which dietary protein digestion and absorption and the subsequent muscle protein synthetic response were assessed in vivo in 2 healthy men.

\section{MATERIALS AND METHODS}

\section{Production of Intrinsically Labeled Milk Protein}

Tracers. $\mathrm{L}-\left[1-{ }^{13} \mathrm{C}\right]$ Phenylalanine (99\% enriched) was obtained from Cambridge Isotopes Laboratories (Andover, MA). A total of $400 \mathrm{~g}$ of $\mathrm{L}-\left[1-{ }^{13} \mathrm{C}\right]$ phenylalanine tracer was dissolved in $24 \mathrm{~L}$ of deionized water, sterilized, and used to produce intrinsically labeled milk proteins.

Animals. Two healthy Holstein dairy cows from the experimental INRA (UMR1080 Dairy Production) farm of Mejusseaume (France) were used for the production of $\mathrm{L}-\left[1-{ }^{13} \mathrm{C}\right]$ phenylalanine-labeled milk proteins. The cows were at the beginning of lactation $(726 \pm 38 \mathrm{~kg}$ of BW, at $26 \pm 2 \mathrm{~d}$ of lactation) and produced $50 \pm 1$ $\mathrm{kg} / \mathrm{d}$ of milk at $27.7 \pm 1.3 \mathrm{~g} / \mathrm{kg}$ of true protein content (i.e., $1,379 \pm 18 \mathrm{~g} / \mathrm{d}$ of protein yield) during the experiment. They received a maize silage-based diet (62.5\%) supplemented with dried lucerne $(8.2 \%), 2$ soybean meal concentrates (15.9\%), an energy concentrate (11.9\%), Smartamine M (1.8\%; Adisseo France SAS, Antony, France), and minerals (1.32\%). During the experiment, cows consumed $23.3 \mathrm{~kg}$ of DM/d, which covered $80 \%$ of the energy requirements and was near the equilibrium for protein requirements (96\% of protein digestible in the intestine). The animals had access to the food every $3 \mathrm{~h}$ starting at $0700 \mathrm{~h}$ to maintain constant plasma phenylalanine and tyrosine concentrations and enrichments. The animals were housed in an individual tie stall under a continuous lighting regimen and had free access to water. The applied infusion protocol was in accordance with the French Animal Care guidelines.

Infusion Schedule. An outline of the applied infusion protocol is shown in Figure 1. One week before the start of the infusion experiment, milk was collected for $48 \mathrm{~h}$ (unlabeled milk, UL). One day before infusion, catheters (silastic, $30 \mathrm{~cm}$ length, $1.02 \mathrm{~mm}$ i.d. $\times 2.16$ mm o.d., Silclear Tubing, Degania, Israel) were inserted percutaneously in a jugular vein for infusion and for sampling in the tail artery (Intraflon 121.21, $30 \mathrm{~mm}$ length, $1 \mathrm{~mm}$ i.d. $\times 1.1 \mathrm{~mm}$ o.d., Vygon, Ecouen, France) and in the left mammary vein (Tygon, $30 \mathrm{~cm}$ length, 1.1 mm i.d. $\times 2.2$ mm o.d., Tygon, Saint Herblain, France) Catheters were filled with $0.9 \%$ saline containing heparin $(20 \mathrm{IU} / \mathrm{mL}$ between sampling and $200 \mathrm{IU} / \mathrm{mL}$ at the end of sampling day) and dihydrostreptomycine (Intervet, Beaucouzé, France) and secured to the skin as described previously (Boirie et al., 1995). A total of $23 \mathrm{~L}$ of infusate was infused for 44 (cow 1) and 48 (cow 2) h (Figure 1). At $0630 \mathrm{~h}$, immediately after milking, infusion of $\left[1-{ }^{13} \mathrm{C}\right]$ phenylalanine was started via the jugular vein using a peristaltic pump at a rate of 4.16 $\mathrm{mL} / \mathrm{min}\left(402 \mu \mathrm{mol}\right.$ of $\mathrm{L}-\left[1-{ }^{13} \mathrm{C}\right]$ phenylalanine/min) for 44 to $48 \mathrm{~h}$. The cows were milked every $12 \mathrm{~h}$ during infusion (Figure 1) and for $24 \mathrm{~h}$ following cessation of infusion. Blood samples were obtained at regular intervals from the tail artery at 1400,1500 , and $1600 \mathrm{~h}$ on d 2 (background) and at 1200, 1300, 1400, 1500, 1600, and $1700 \mathrm{~h}$ on $\mathrm{d} 8$ and 9 (Figure 1). All procedures were well tolerated by the cows.

Casein and Whey Separation. Collected milk was stored at $2^{\circ} \mathrm{C}$ in $100-\mathrm{L}$ containers and pooled in batches 1 (UL), 2 (highly labeled, HL), and 3 (low labeled, LL) as shown in Figure 1 before being treated at INRA (UMR125, Rennes Cedex, France). When all milk of a particular batch was collected, milk was weighed, heated to $40^{\circ} \mathrm{C}$, and skimmed using a cream 


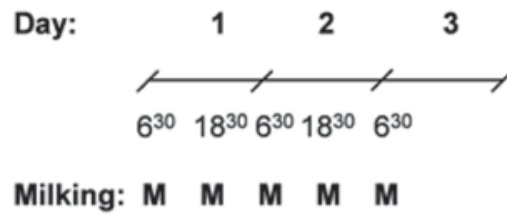

Blood draw:

Cow 1 Batch 1: UL

Cow 2

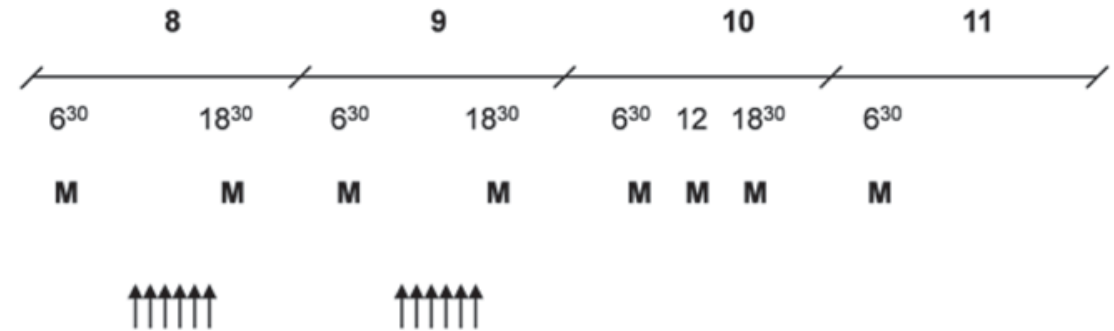

$\mathrm{L}-\left[1-{ }^{13} \mathrm{C}\right]$ Phenylalanine infusion Batch 2: HL

Batch 1: UL

$\mathrm{L}-\left[1-{ }^{13} \mathrm{C}\right]$ Phenylalanine infusion

Batch 2: $\mathrm{HL}$

Batch 3: LL

Figure 1. Outline of the L- $\left[1-{ }^{13} \mathrm{C}\right]$ phenylalanine infusion in 2 cows. Milk was collected from 2 cows into 3 batches: UL $=$ unlabeled milk, collected before isotope infusion; $\mathrm{HL}=$ highly labeled milk, collected during isotope infusion; LL = low-labeled milk, collected after cessation of isotope infusion.

separator (about $200 \mathrm{~L} / \mathrm{h}$ ). The cream was weighed and discarded. The skimmed milk was transported to another milk container for microbial cleaning. The milk was cleaned by means of a Sterilox GP membrane with pore size of $1.4 \mu \mathrm{m}$ (ceramique Pall-Exekia, Bazet, France) at $40^{\circ} \mathrm{C}, 110 \mathrm{kPa}$ of transmembrane pressure, $400 \mathrm{~L} / \mathrm{h}$. The retentate was diafiltrated with sterile reverse osmosis water. The milk was collected in a storage tank at $40^{\circ} \mathrm{C}$ and continuously processed to the casein separator. The milk was filtered over a MembraLox membrane $(0.1 \mu \mathrm{m}$, Pall-Exekia) to separate casein micelles from soluble whey proteins. The separation was performed at $50^{\circ} \mathrm{C}$, transmembrane pressure of 50 to $60 \mathrm{kPa}$, and $300 \mathrm{~L} / \mathrm{h}$. The micellar casein solution retentate was diafiltrated and concentrated to about $9 \%$ DM (containing 90\% protein). The concentrated casein solution was collected, weighed, and frozen at $-20^{\circ} \mathrm{C}$. The soluble whey protein fraction (passing the $0.1-\mu \mathrm{m}$ membrane) was collected and further concentrated by means of an $8 \mathrm{kDa}$ membrane. The retentate, containing the protein fraction, was diafiltrated with sterile reverse osmosis water until a low lactose concentration was reached ( $1 \%$ of original milk content). The permeate stream was collected temporarily in a cooled tank (Westfalia separator, Westfalia Separator Industries SAS, Château-Thierry Cedex, France) to avoid spoilage in case of ultrafilter leakage. The protein fraction was concentrated about 6 times to a final concentration of about $3 \%$ protein. The whey protein solution was collected, filtered through a $0.2-\mu \mathrm{m}$ filter, weighed, and stored at $-20^{\circ} \mathrm{C}$.

Cow Plasma and Milk Protein Analyses. Plasma phenylalanine and tyrosine were derivatized to their t-butyldimethylsilyl (TBDMS) derivatives, and their ${ }^{13} \mathrm{C}$ enrichments were determined by electron ionization GC-MS (Agilent 6890N GC/5973N mass selective detector, Agilent, Little Falls, NJ) using selected ion monitoring of masses 336 and 337 for unlabeled and labeled L- $\left[1-{ }^{13} \mathrm{C}\right]$ phenylalanine, respectively, and masses 466 and 467 for unlabeled and labeled L- $\left[1-{ }^{13} \mathrm{C}\right]$ tyrosine (Wolfe, 1992). We applied standard regression curves in all isotopic enrichment analyses to assess linearity of the mass spectrometer and to control for the loss of tracer. For measurement of $\mathrm{L}-\left[1-{ }^{13} \mathrm{C}\right]$ phenylalanine and $\mathrm{L}-\left[1-{ }^{13} \mathrm{C}\right]$ tyrosine enrichments in the intrinsically labeled milk protein, $100 \mu \mathrm{L}$ of milk was added to $900 \mu \mathrm{L}$ of $2 \%$ ice-cold perchloric acid (PCA). The mixture was vortexed, kept on ice for $10 \mathrm{~min}$, and centrifuged at 3,500 $\times g$. The protein pellet was washed with 3 additional $1.5-\mathrm{mL}$ washes of $2 \% \mathrm{PCA}$, dried, and hydrolyzed in 6 $M \mathrm{HCl}$ at $120^{\circ} \mathrm{C}$ for 15 to $18 \mathrm{~h}$. The hydrolyzed protein fraction was dried under a nitrogen stream while being heated to $120^{\circ} \mathrm{C}$, after which $50 \%$ acetic acid solution was added. The hydrolyzed protein was passed over a Dowex exchange resin (AG 50W-X8, 100-200 mesh hydrogen form, BioRad, Hercules, CA) using $2 \mathrm{M} \mathrm{NH}_{4} \mathrm{OH}$. 
Thereafter, the eluate was dried and the purified AA were derivatized to their $N(O, S)$-ethoxycarbonyl ethyl esters for the determination of ${ }^{13} \mathrm{C} /{ }^{12} \mathrm{C}$ ratios of milk protein-bound phenylalanine and tyrosine (Husek, 1991). Thereafter, the derivative was measured by GCisotope ratio mass spectrometry (Finnigan MAT 252, Bremen, Germany) using an HP Ultra I GC-column (19091A-112, Hewlett-Packard, Palo Alto, CA), combustion interface II, and monitoring of ion masses 44, 45, and 46. By establishing the relationship between the enrichment of a series of $\mathrm{L}-\left[1-{ }^{13} \mathrm{C}\right]$ phenylalanine and $\mathrm{L}-\left[1-{ }^{13} \mathrm{C}\right]$ tyrosine standards of variable enrichment and the enrichment of the $N(O, S)$-ethoxycarbonyl ethyl esters of these standards, the milk protein-bound enrichment of phenylalanine and tyrosine were determined. We applied standard regression curves to assess linearity of the mass spectrometer and to control for loss of tracer.

\section{Human Proof-of-Principle Study}

Tracers. L- $\left[\right.$ ring- $\left.{ }^{2} \mathrm{H}_{5}\right]$ Phenylalanine (98\% enriched), L- $\left[\right.$ ring $\left.-{ }_{-}^{2} \mathrm{H}_{2}\right]$ tyrosine $\left(98 \%\right.$ enriched), and L- $\left[1-{ }^{13} \mathrm{C}\right]$ leucine (99\% enriched) were obtained from Cambridge Isotopes Laboratories. L- $\left[\right.$ ring- $\left.^{2} \mathrm{H}_{5}\right]$ Phenylalanine, L- $\left[\right.$ ring $\left._{-}{ }^{2} \mathrm{H}_{2}\right]$ tyrosine, and $\mathrm{L}-\left[1-{ }^{13} \mathrm{C}\right]$ leucine were dissolved in sterile $0.9 \%$ saline for the infusion in human volunteers as described previously (Koopman et al., 2006, 2008).

Subjects. Two healthy, normoglycemic male volunteers (age: $61 \pm 1 \mathrm{yr}$; weight: $69.7 \pm 4.9 \mathrm{~kg}$; body mass index: $22.4 \pm 0.1 \mathrm{~kg} / \mathrm{m}^{2}$; basal glucose: $5.2 \pm 0.2$ $\mathrm{mmol} / \mathrm{L}$; basal insulin: $6.8 \pm 0.5 \mathrm{mU} / \mathrm{L}$ ) with no history of participating in any regular exercise program were selected to participate in the present study. All subjects were informed on the nature and possible risks of the experimental procedures before their written informed consent was obtained. This study was approved by the Medical Ethics Committee of the Academic Hospital Maastricht.

Protocol. At 0800 h, following an overnight fast, subjects arrived at the laboratory by car or public transportation. A Teflon catheter was inserted into an antecubital vein for stable isotope infusion. A second Teflon catheter was inserted in a heated dorsal hand vein of the contralateral arm and placed in a hot-box $\left(60^{\circ} \mathrm{C}\right)$ for arterialized blood sampling. After basal blood sample collection $(t=-120 \mathrm{~min})$, plasma phenylalanine, leucine, and tyrosine pools were primed with a single intravenous dose of the amino acid tracers [L- $\left[\right.$ ring- $\left.{ }^{2} \mathrm{H}_{5}\right]$ phenylalanine $(2 \mu \mathrm{mol} / \mathrm{kg}), \mathrm{L}-\left[\right.$ ring- $\left.{ }^{2} \mathrm{H}_{2}\right]$ tyrosine $(0.775 \mu \mathrm{mol} / \mathrm{kg})$ and $\mathrm{L}-\left[1-{ }^{13} \mathrm{C}\right]$ leucine $(5.06$ $\mu \mathrm{mol} / \mathrm{kg})]$. Thereafter, continuous tracer infusion was started (infusion rate of $0.046 \pm 0.001 \mu \mathrm{mol} / \mathrm{kg}$ per min for L- $\left[\right.$ ring- $\left.^{2} \mathrm{H}_{5}\right]$ phenylalanine, $0.017 \pm 0.000 \mu \mathrm{mol} /$ $\mathrm{kg}$ per min for L- $\left[\right.$ ring $\left._{-}{ }^{2} \mathrm{H}_{2}\right]$ tyrosine, and $0.110 \pm 0.002$ $\mu \mathrm{mol} / \mathrm{kg}$ per min for $\mathrm{L}-\left[1-{ }^{13} \mathrm{C}\right]$ leucine). Subjects rested in a supine position for $2 \mathrm{~h}$, after which an arterialized blood sample and a muscle biopsy from the vastus lateralis muscle were collected $(t=0 \mathrm{~min})$. Subjects then received a bolus of a given test drink containing $35 \mathrm{~g}$ of protein intrinsically labeled with $\mathrm{L}-\left[1-{ }^{13} \mathrm{C}\right]$ phenylalanine. Arterialized blood samples were collected at $t=$ $15,30,45,60,75,90,120,135,150,165,180,210,240$, $270,300,330$, and 360 min with a second muscle biopsy taken at $t=360 \mathrm{~min}$ from the contralateral limb. Blood samples were collected in EDTA tubes and centrifuged at $1,000 \times \mathrm{g}$ and $4^{\circ} \mathrm{C}$ for $5 \mathrm{~min}$. Aliquots of plasma were frozen in liquid nitrogen and stored at $-80^{\circ} \mathrm{C}$. Muscle biopsies were obtained from the middle region of the vastus lateralis (15 cm above the patella) and approximately $3 \mathrm{~cm}$ below entry through the fascia using the percutaneous needle biopsy technique (Bergstrom, 1975). Muscle samples were dissected carefully and freed from any visible nonmuscle material. The muscle sample was immediately frozen in liquid nitrogen and stored at $-80^{\circ} \mathrm{C}$ until analysis.

Beverage Composition. Subjects received a beverage volume of $350 \mathrm{~mL}$ to ensure a given dose of $35 \mathrm{~g}$ of $\mathrm{L}-\left[1-{ }^{13} \mathrm{C}\right]$ phenylalanine-labeled casein protein (providing $0.070 \pm 0.001 \mathrm{~g}$ of $\mathrm{N}, 154 \pm 5 \mu \mathrm{mol}$ of phenylalanine, $153 \pm 5 \mu \mathrm{mol}$ of tyrosine, and $350 \pm 11 \mu \mathrm{mol}$ of leucine $/ \mathrm{kg}$ of $\mathrm{BW})$. Beverages were flavored by adding $0.375 \mathrm{~g}$ of sodium-saccharinate, $0.9 \mathrm{~g}$ of citric acid, and $5 \mathrm{~mL}$ of vanilla flavor (Quest International, Naarden, the Netherlands) for each liter of beverage.

Plasma Analyses. For plasma enrichment measurements, phenylalanine, tyrosine, and leucine were derivatized to their TBDMS derivatives, and their ${ }^{13} \mathrm{C}$ or ${ }^{2} \mathrm{H}$ enrichments were determined by electron ionization GC-MS (6890N GC/5973N MSD, Agilent) using selected ion monitoring of masses 336, 337, and 341 for unlabeled and labeled $\left(1-{ }^{13} \mathrm{C}\right.$ and ring- $\left.{ }^{2} \mathrm{H}_{5}\right)$ phenylalanine, respectively; masses 466, 467, 468, and 470 for unlabeled and labeled $\left(1-{ }^{13} \mathrm{C}\right.$, ring- ${ }^{2} \mathrm{H}_{2}$, and ring- $\left.{ }^{2} \mathrm{H}_{4}\right)$ tyrosine, respectively, and masses 302 and 303 for unlabeled and labeled leucine (Wolfe, 1992). For plasma ketoisocaproic acid (KIC) enrichment measurements, plasma KIC was derivatized to its N-methyl-N-(tbutyldimethylsilyl)trifluoroacetamide derivative, and its ${ }^{13} \mathrm{C}$ enrichments were assessed by monitoring of masses 301 and 302 for unlabeled and labeled KIC, respectively (Dangin et al., 2003). We applied standard regression curves in all isotopic enrichment analyses to assess linearity of the mass spectrometer and to control for the loss of tracer.

Muscle Sample Analyses. For measurement of $\mathrm{L}-\left[1-{ }^{13} \mathrm{C}\right]$ phenylalanine and $\mathrm{L}-\left[1-{ }^{13} \mathrm{C}\right]$ leucine enrichment in mixed muscle protein, $55 \mathrm{mg}$ of wet muscle was freeze- 
dried. Collagen, blood, and other nonmuscle fiber material were removed from the muscle fibers under a light microscope. The isolated muscle fiber mass $(2-3 \mathrm{mg})$ was weighed and 8 volumes $(8 \times$ dry weight of isolated muscle fibers $\times$ wet/dry ratio) of ice-cold $2 \%$ PCA were added. The tissue was then homogenized and centrifuged. The protein pellet was washed with 3 additional 1.5-mL washes of $2 \%$ PCA, dried, and hydrolyzed in 6 $M \mathrm{HCl}$ at $120^{\circ} \mathrm{C}$ for 15 to $18 \mathrm{~h}$. The hydrolyzed protein fraction was dried under a nitrogen stream while being heated to $120^{\circ} \mathrm{C}$, and then $50 \%$ acetic acid solution was added to 1 vial, and the hydrolyzed protein was passed over a Dowex exchange resin (AG 50W-X8, 100-200 mesh hydrogen form, BioRad) using $2 \mathrm{M} \mathrm{NH}_{4} \mathrm{OH}$. Thereafter, the eluate was dried and the purified AA were derivatized to their $N(O, S)$-ethoxycarbonyl ethyl esters for the determination of ${ }^{13} \mathrm{C} /{ }^{12} \mathrm{C}$ ratios of muscle protein-bound phenylalanine and leucine (Husek, 1991). Thereafter, the derivative was measured by GC-IRMS (Finnigan MAT 252) using an HP Ultra I GC-column (\#19091A-112, Hewlett-Packard), combustion interface II, and monitoring of ion masses 44, 45, and 46. By establishing the relationship between the enrichment of a series of $\mathrm{L}-\left[1-{ }^{13} \mathrm{C}\right]$ phenylalanine and $\mathrm{L}-\left[1-{ }^{13} \mathrm{C}\right]$ leucine standards of variable enrichment and the enrichment of the $N(O, S)$-ethoxycarbonyl ethyl esters of these standards, the muscle protein-bound enrichment of phenylalanine and leucine were determined. We applied standard regression curves to assess linearity of the mass spectrometer and to control for loss of tracer. The coefficient of variance for the measurement of $\mathrm{L}_{-}\left[1-{ }^{13} \mathrm{C}\right]$ phenylalanine and L- $\left[1-{ }^{13} \mathrm{C}\right]$ leucine enrichment in mixed muscle protein averaged $1.0 \pm 0.1$ and $1.1 \pm 0.1 \%$, respectively.

Calculations. Ingestion of $\mathrm{L}-\left[1-{ }^{13} \mathrm{C}\right]$ phenylalaninelabeled protein, intravenous infusion of L- $\left[\right.$ ring- $\left.^{2} \mathrm{H}_{5}\right]$ phenylalanine, L- $\left[\right.$ ring $\left._{-}{ }^{2} \mathrm{H}_{2}\right]$ tyrosine, and $\mathrm{L}-\left[1-{ }^{13} \mathrm{C}\right]$ leucine, and arterialized blood sampling were used to assess whole-body AA kinetics in non-steady-state conditions. Total, exogenous, and endogenous rate of appearance $\left(\boldsymbol{R}_{a}\right)$ and splanchnic extraction (i.e., fraction of dietary AA taken up by the gut and liver during first pass, $\boldsymbol{S p}$ ) for phenylalanine were calculated using modified Steele's equations (Boirie et al., 1996; Dangin et al., 2003). These parameters were calculated as follows:

$$
\begin{gathered}
\text { Total } R_{a}=\frac{F-p V \times C(t) \times \mathrm{d} E_{i v} / \mathrm{d} t}{E_{i v} t}, \\
\text { Exo } R_{a}=\frac{\text { Total } R_{a} \times E_{p o}(t)+p V \times \mathrm{d} E_{p o} / \mathrm{d} t}{E_{p r o t}}, \\
\text { Endo } R_{a}=\text { Total } R_{a}-\text { Exo } R_{a}-F,
\end{gathered}
$$

$$
S p=100 \times\left(\frac{\text { Phe }_{\text {Prot }}-\mathrm{AUC}_{\text {ExoPheRa }}}{\text { Phe }_{\text {Prot }}}\right),
$$

where $F$ is the intravenous tracer infusion rate $(\mu \mathrm{mol} /$ $\mathrm{kg}$ per min), $p V(0.125)$ is the distribution volume for phenylalanine (Engelen et al., 2003), $C(t)$ is the mean plasma phenylalanine concentration between 2 time points, $\mathrm{d} E_{i v} / \mathrm{d} t$ represents the time-dependent variations of plasma phenylalanine enrichment (expressed in tracer-tracee ratio; TTR) derived from the intravenous tracer, and $E_{i v}(t)$ is the mean plasma phenylalanine enrichment from the intravenous tracer between 2 consecutive time points; Exo $R_{a}$ represents the plasma entry rate of dietary phenylalanine, $E_{p o}(t)$ is the mean plasma phenylalanine enrichment for the oral tracer, $\mathrm{d} E_{p o} / \mathrm{d} t$ represents the time-dependent variations of plasma phenylalanine enrichment derived from the oral tracer, and $E_{\text {prot }}$ is the L- $\left[1-{ }^{13} \mathrm{C}\right]$ phenylalanine enrichment in the dietary protein; Phe Prot $_{\text {is }}$ the amount of dietary phenylalanine ingested, $\mathrm{AUC}_{\text {ExoPheRa }}$ represents the area under the curve of ExoPhe $R_{a}$, which corresponds to the amount of dietary phenylalanine that appeared in the blood over a 6 -h period following protein ingestion.

Total rate of disappearance $\left(R_{d}\right)$ of phenylalanine equals the rate of phenylalanine hydroxylation and utilization for protein synthesis. These parameters can be calculated as follows:

$$
R_{d}=\text { Total } R_{a}-p V \times \frac{\mathrm{d} C}{\mathrm{~d} t},
$$

$$
\text { Phe hydroxylation }=\text { Tyr } R_{a} \times \frac{E_{p}(t)}{E_{t}(t)} \times \frac{\text { Phe } R_{d}}{\left(F_{p}+\text { Phe } R_{d}\right)} \text {, }
$$

protein synthesis $=$ Total $R_{d}-$ Phe hydroxylation,

Phe net balance $=$ Protein synthesis - Endo $R_{a}$.

where $E_{t}(t)$ and $E_{p}(t)$ represent the mean plasma L[ring- ${ }_{-}^{2} \mathrm{H}_{4}$ ] tyrosine and L-[ring- ${ }^{2} \mathrm{H}_{5}$ ] phenylalanine enrichment between 2 consecutive time points, respectively.

Fractional rate of mixed muscle protein synthesis (FSR) was calculated by dividing the increment in enrichment in the product; that is, protein-bound L- $\left[1-{ }^{13} \mathrm{C}\right]$ phenylalanine, and $\mathrm{L}-\left[1-{ }^{13} \mathrm{C}\right]$ leucine, by the enrichment of the precursor. Plasma $\mathrm{L}_{-}\left[1-{ }^{13} \mathrm{C}\right]$ phenylalanine, and $\mathrm{L}-\left[1-{ }^{13} \mathrm{C}\right] \mathrm{KIC}$ enrichments were used to provide an es- 


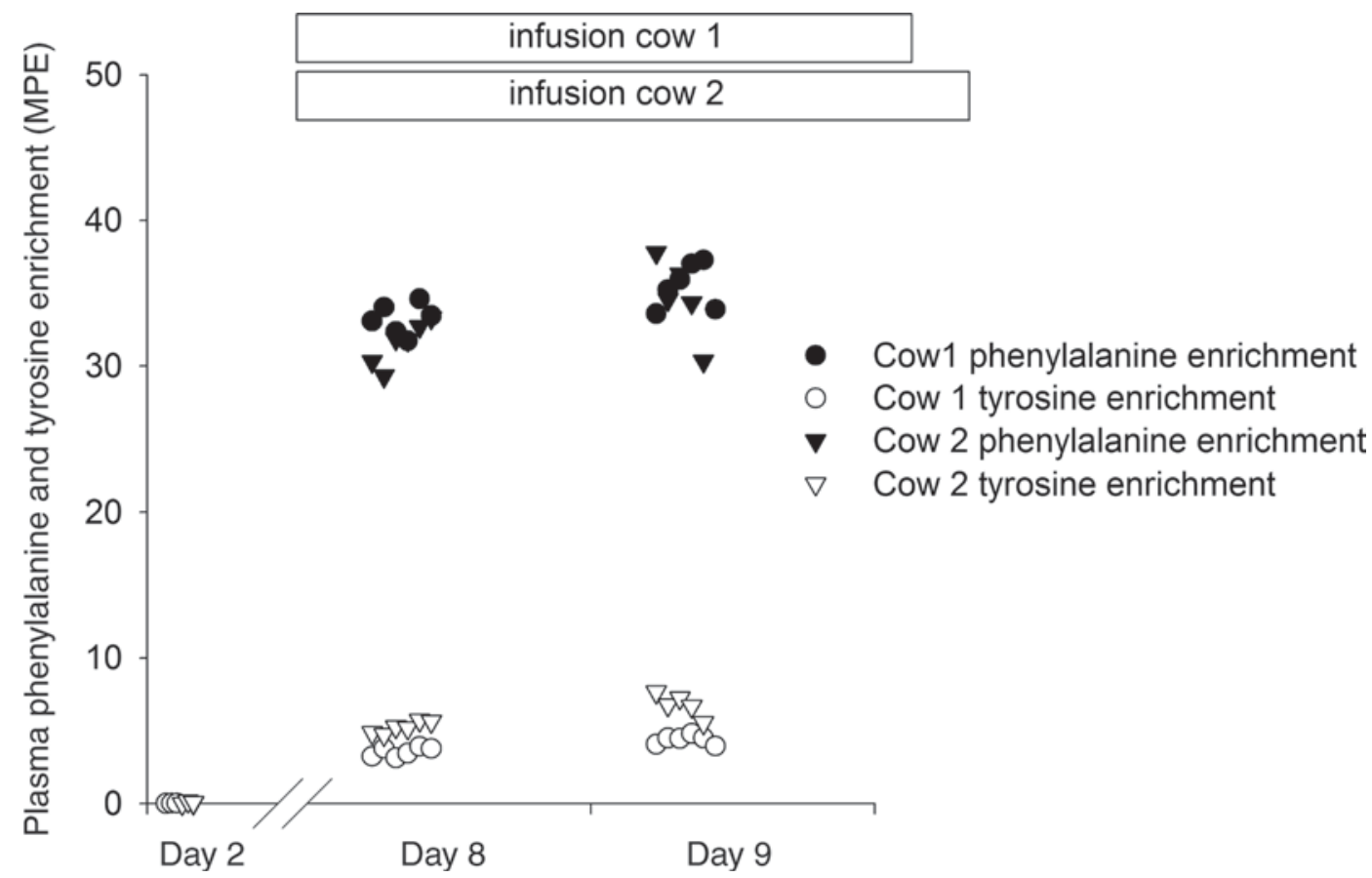

Figure 2. Plasma L- $\left[1-{ }^{13} \mathrm{C}\right]$ phenylalanine and L- $\left[1-{ }^{13} \mathrm{C}\right]$ tyrosine enrichment (mole percent excess, MPE) in samples collected before and during 44 to $48 \mathrm{~h}$ of $\mathrm{L}-\left[1-{ }^{13} \mathrm{C}\right]$ phenylalanine infusion in 2 cows.

timate for the true fractional synthesis rate of mixed muscle proteins. Plasma $\mathrm{L}-\left[1-{ }^{13} \mathrm{C}\right] \mathrm{KIC}$ was used as precursor instead of plasma $\mathrm{L}_{-}\left[1-{ }^{13} \mathrm{C}\right]$ leucine enrichment as it has been shown to be more representative of the intracellular leucine enrichment (Chow et al., 2006). Muscle FSR were calculated as follows (Koopman et al., 2005):

$$
F S R=\frac{\Delta E_{p}}{E_{\text {precursor }} \times t} \times 100,
$$

where $\Delta E_{p}$ is the delta increment of protein-bound $\mathrm{L}-\left[1-{ }^{13} \mathrm{C}\right]$ phenylalanine or L- $\left[1-{ }^{13} \mathrm{C}\right]$ leucine, during incorporation periods; $E_{\text {precursor }}$ is the average plasma $\mathrm{L}-\left[1-{ }^{13} \mathrm{C}\right]$ phenylalanine or $\mathrm{L}-\left[1-{ }^{13} \mathrm{C}\right] \mathrm{KIC}$ enrichment during the time period for determination of AA incorporation (Wagenmakers, 1999); and $t$ indicates the time interval (h) between biopsies. All data are expressed as means \pm SEM.

\section{RESULTS}

\section{Production of Intrinsically Labeled Milk Protein}

Infusion of $\mathrm{L}-\left[1-{ }^{13} \mathrm{C}\right]$ phenylalanine in the 2 cows substantially increased arterial plasma $\mathrm{L}-\left[1-{ }^{13} \mathrm{C}\right]$ phenylalanine enrichment (Figure 2). During the 44- to 48-h infusion period, arterial plasma L- $\left[1-{ }^{13} \mathrm{C}\right]$ phenylalanine enrichment averaged $33.97 \pm 0.83$ and $32.96 \pm 0.79$ mole percent excess (MPE) in cows 1 and 2, respectively. As a result of the $\mathrm{L}-\left[1-{ }^{13} \mathrm{C}\right]$ phenylalanine infusion, plasma $\mathrm{L}-\left[1-{ }^{13} \mathrm{C}\right]$ tyrosine enrichment also increased during the experiment and averaged $4.79 \pm 0.79$ and $5.93 \pm 0.30$ MPE in cows 1 and 2, respectively.

Figure 3 shows the results of L- $\left[1-{ }^{13} \mathrm{C}\right]$ phenylalanine infusion on $\mathrm{L}-\left[1-{ }^{13} \mathrm{C}\right]$ phenylalanine enrichment in the milk protein. $\mathrm{L}-\left[1-{ }^{13} \mathrm{C}\right]$ Phenylalanine enrichment in the milk averaged 29.4 versus $6.1 \mathrm{MPE}$ in batch 2 (collected during infusion) and batch 3 (collected following infusion), respectively. Milk $\mathrm{L}-\left[1-{ }^{13} \mathrm{C}\right]$ tyrosine enrichment averaged 4.4 versus $1.1 \mathrm{MPE}$ in batches 2 and 3 , respectively.

In total, cows produced 241, 210, and $88 \mathrm{~kg}$ of UL (batch 1), HL (batch 2), and LL (batch 3) milk, respectively, containing $2.8 \%$ protein (Table 1 ). The total casein yield from the collected milk was $4.8,4.8$, and $2.0 \mathrm{~kg}$ for batches 1, 2, and 3, respectively. A total of $0.6,0.6$, and $0.5 \mathrm{~kg}$ of whey protein was isolated from batches 1,2 , and 3 , respectively (Table 2 ).

\section{Human Proof-of-Principle Study}

The time course of the plasma L- $\left[1-{ }^{13} \mathrm{C}\right]$ phenylalanine and L- $\left[\right.$ ring- $\left.^{2} \mathrm{H}_{5}\right]$ phenylalanine enrichments in the human experiment are illustrated in Figure 4A. The plasma 
Table 1. Milk production and protein yield during different stages of the cow infusion experiments

\begin{tabular}{lcc}
\hline Batch & Milk $(\mathrm{kg})$ & Protein yield $(\mathrm{kg})$ \\
\hline 1 & 241 & 6.770 \\
2 & 210 & 5.833 \\
3 & 88 & 2.497 \\
\hline
\end{tabular}

$\mathrm{L}-\left[1-{ }^{13} \mathrm{C}\right]$ phenylalanine enrichment (derived from the intrinsically labeled protein) rapidly increased after protein ingestion and subsequently declined over time. The plasma L- $\left[\right.$ ring- $^{2} \mathrm{H}_{5}$ ]phenylalanine enrichment decreased following the ingestion of $\mathrm{L}_{-}\left[1-{ }^{13} \mathrm{C}\right]$ phenylalanine-labeled casein protein, after which levels increased toward basal values. The plasma $\mathrm{L}-\left[1-{ }^{13} \mathrm{C}\right]$ phenylalanine and $\mathrm{L}-\left[1-{ }^{13} \mathrm{C}\right]$ KIC enrichments during the experiment averaged 0.08 \pm 0.02 and $0.07 \pm 0.01$ (TTR), respectively.

Ingestion of the intrinsically labeled protein resulted in a rapid increase in appearance rate of exogenous phenylalanine (Figure 4B). In contrast, appearance rates of endogenous phenylalanine decreased over time following ingestion of the protein. The calculated percentage of ingested phenylalanine taken up by the splanchnic area during its first pass (i.e., the amount of ingested phenylalanine not appearing in plasma) averaged $74 \pm 4 \%$. The increase in protein-bound $\mathrm{L}-\left[1-{ }^{13} \mathrm{C}\right]$ phenylalanine and $\mathrm{L}-\left[1-{ }^{13} \mathrm{C}\right]$ leucine enrichment averaged $0.00025 \pm 0.00001$ and $0.00023 \pm 0.00001$, respectively.
Table 2. Casein and whey protein production during different stages of the cow infusion experiments

\begin{tabular}{lcl}
\hline Batch & Whey protein solution $(\mathrm{kg})$ & Casein solution $(\mathrm{kg})$ \\
\hline 1 & $31.8(2 \% \mathrm{wt} / \mathrm{vol})$ & $53(9 \% \mathrm{wt} / \mathrm{vol})$ \\
2 & $31.8(2 \% \mathrm{wt} / \mathrm{vol})$ & $53.7(9 \% \mathrm{wt} / \mathrm{vol})$ \\
3 & $23.6(2 \% \mathrm{wt} / \mathrm{vol})$ & $15.7(13 \% \mathrm{wt} / \mathrm{vol})$ \\
\hline
\end{tabular}

Skeletal muscle protein FSR calculated using L- $\left[1-{ }^{13} \mathrm{C}\right]$ phenylalanine as a tracer averaged $0.058 \pm 0.012 \% / \mathrm{h}$. Using $\mathrm{L}-\left[1-{ }^{13} \mathrm{C}\right]$ leucine as a tracer, the FSR during the 6 -h measuring period was $0.061 \pm 0.001 \% / \mathrm{h}$.

\section{DISCUSSION}

The present study shows that milk proteins intrinsically labeled with $\left[1-{ }^{13} \mathrm{C}\right]$ phenylalanine can be produced by collecting milk from cows infused with large quantities of $\left[1-{ }^{13} \mathrm{C}\right]$ phenylalanine. Levels of $\left[1-{ }^{13} \mathrm{C}\right]$ phenylalanine enrichment in milk protein as high as approximately $30 \mathrm{MPE}$ are feasible. The ability to produce dietary protein with such high levels of intrinsic isotope labeling allows the assessment of protein digestion and absorption, and the subsequent postprandial skeletal muscle protein synthetic response in vivo in humans.

For many years, stable isotope-labeled AA have been applied to study protein metabolism in vivo in humans. The application of this technique has led to important

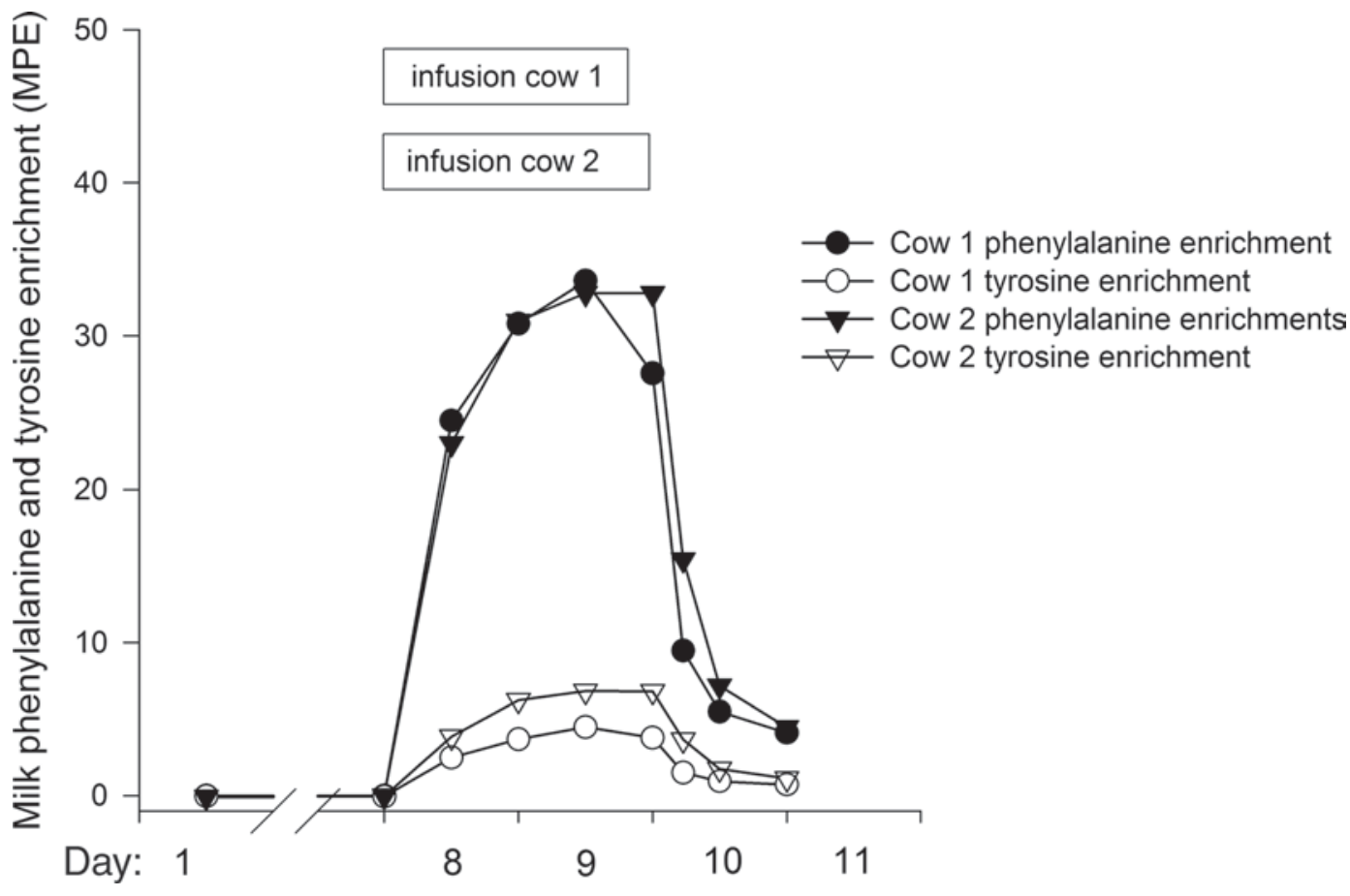

Figure 3. L- $\left[1-{ }^{13} \mathrm{C}\right]$ Phenylalanine and L- $\left[1-{ }^{13} \mathrm{C}\right]$ tyrosine enrichment (mole percent excess, MPE) of the milk samples collected before, during, and after 44 to $48 \mathrm{~h}$ of L- $\left[1-{ }^{13} \mathrm{C}\right]$ phenylalanine infusion in 2 cows. 

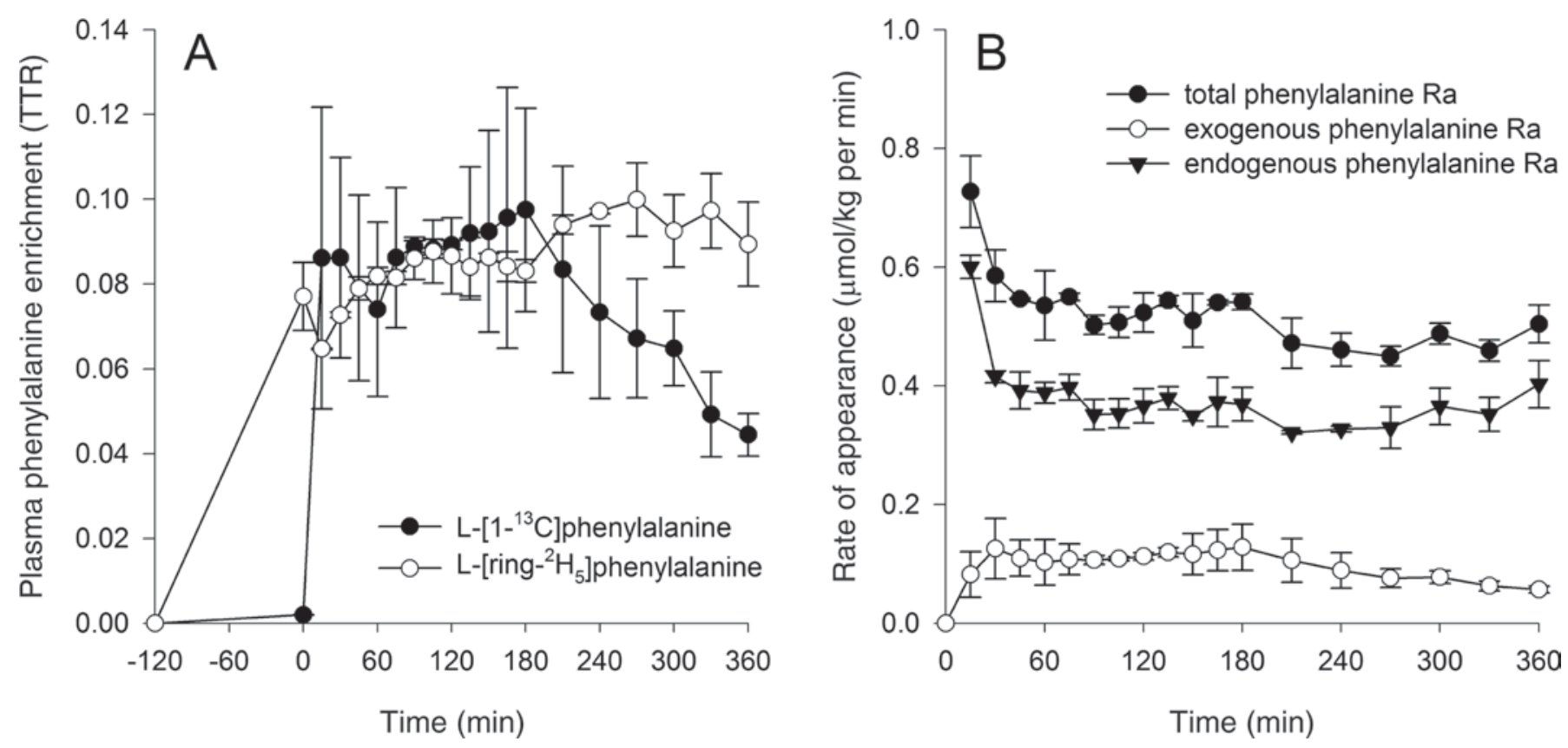

Figure 4. Plasma L- $\left[1-{ }^{13} \mathrm{C}\right]$ phenylalanine and L- $\left[\right.$ ring $\left._{-}{ }^{2} \mathrm{H}_{5}\right]$ phenylalanine enrichments (A) and plasma exogenous, total, and endogenous phenylalanine appearance rate $(\mathrm{B} ; \mathrm{Ra}, \mu \mathrm{mol} / \mathrm{kg}$ per min) following ingestion of a bolus of intrinsically labeled casein in healthy, elderly men ( $\mathrm{n}=$ 2). Values represent means + SEM. TTR $=$ tracer-tracee ratio.

physiological insights and has provided a wealth of practical information on the effect of nutrition and exercise on maintaining and increasing skeletal muscle mass in both health and disease (Koopman et al., 2007b). Most studies generally investigate the turnover of a specific AA through isotope dilution via continuous intravenous administration of a labeled AA. However, when investigating the effect of feeding on protein metabolism, most groups apply a research design in which labeled leucine or phenylalanine is administered orally, with or without continuous infusion of an intravenous AA tracer. The fact that the oral tracer is being administered as a free $\mathrm{AA}$ and the bulk of AA are provided as intact dietary protein introduces substantial methodological limitations (Boirie et al., 1995). Free AA and protein-derived AA exhibit entirely different timing and efficiency of intestinal absorption (Boirie et al., 1996). Therefore, to directly assess the digestion and absorption kinetics of dietary protein in vivo in humans, we need intrinsically labeled dietary proteins. However, dietary proteins with a labeled AA incorporated within the dietary protein source are not commercially available and only a few reports describe the production of stable isotope-labeled proteins for more specific purposes (Irving et al., 1988; Berthold et al., 1991; Hutchens et al., 1991; Boirie et al., 1995; Evenepoel et al., 1997; Deglaire et al., 2008). In the present study, we extended previous work by Boirie et al. (1995) by investigating the potential to produce relatively large amounts of proteins highly labeled with $\mathrm{L}-\left[1-{ }^{13} \mathrm{C}\right]$ phenylalanine by intravenous infusion of labeled AA in lactating cows to allow the assessment of the rate of dietary protein digestion and absorption and subsequent muscle protein synthetic response in humans.

Although $\left.{ }^{13} \mathrm{C}\right]$-labeled leucine has generally been applied as an AA tracer to study in vivo human protein metabolism for decades, many groups now prefer the use of labeled phenylalanine for the measurement of muscle protein synthesis (Biolo et al., 1995). Unlike leucine, phenylalanine is not preferentially oxidized and, as such, seems to form a more representative tracer to study overall AA kinetics (Koopman et al., 2004). Furthermore, as leucine has been identified as an important regulating factor behind the postprandial muscle protein synthetic response (Anthony et al., 2001), it is not surprising that many recent studies have investigated the effect of AA or protein ingestion with or without additional free leucine (Koopman et al., 2005, 2006, 2008). It is evident that, in the latter studies, leucine should not be used as an AA tracer to study overall muscle protein metabolism. Therefore, in the present study we aimed to assess the possibility of producing milk protein intrinsically labeled with $\mathrm{L}-\left[1-{ }^{13} \mathrm{C}\right]$ phenylalanine, as opposed to leucine-labeled protein (Boirie et al., 1995). In addition, we aimed to produce intrinsically labeled protein with much higher levels of $\mathrm{L}-\left[1{ }^{13} \mathrm{C}\right]$ phenylalanine enrichment $(\sim 30 \mathrm{MPE})$ compared with L- $\left[1-{ }^{13} \mathrm{C}\right]$ leucine enrichments obtained in 
previous work (10-20 MPE; Boirie et al., 1995). This would be necessary to apply the intrinsically labeled protein to determine digestion and absorption kinetics as well as the subsequent muscle protein synthetic response following ingestion of a meal-like amount of protein in vivo in humans. Our goal was complicated by the fact that milk protein contains only about $3 \%$ phenylalanine compared with approximately $10 \%$ leucine (Boirie et al., 1995). Intravenous infusion of $400 \mathrm{~g}$ of $\mathrm{L}-\left[1-{ }^{13} \mathrm{C}\right]$ phenylalanine over a 44 - to 48 -h period in 2 Holstein cows resulted in blood $\mathrm{L}-\left[1-{ }^{13} \mathrm{C}\right]$ phenylalanine enrichments of more than 30 to $35 \mathrm{MPE}$ (Figure 2). The latter was accompanied by a similar increase in milk L- $\left[1-{ }^{13} \mathrm{C}\right]$ phenylalanine enrichment during isotope infusion (Figure 3). Finally, this led to the production of 4.8- and $0.5-\mathrm{kg}$ batches of highly labeled casein and whey protein, respectively, with a $\mathrm{L}-\left[1-{ }^{13} \mathrm{C}\right]$ phenylalanine enrichment of 29.4 MPE.

The loss of $\mathrm{L}_{-}\left[1-{ }^{13} \mathrm{C}\right]$ phenylalanine via hydroxylation to $\mathrm{L}-\left[1-{ }^{13} \mathrm{C}\right]$ tyrosine, evident from the accompanying increase in L- $\left[1-{ }^{13} \mathrm{C}\right]$ tyrosine enrichment in both blood (Figure 2) and milk (Figure 3) samples, did not prevent the incorporation of $\mathrm{L}-\left[1-{ }^{13} \mathrm{C}\right]$ phenylalanine into the milk protein. In fact, the efficiency of the entire process; that is, the infusion of $\mathrm{L}-\left[1-{ }^{13} \mathrm{C}\right]$ phenylalanine and the subsequent incorporation thereof in the HL and LL batches of intrinsically labeled milk proteins (Tables 1 and 2; Figure 1) was calculated to be $22.1 \%$. The latter is in line with previous measurements by Boirie et al. (1995), who observed a 22.5 and $27.3 \%$ recovery rate of the tracer dose in the collected protein fractions following infusion of 80 to $90 \mathrm{~g}$ of L- $\left[1-{ }^{13} \mathrm{C}\right]$ leucine for 24 to $32 \mathrm{~h}$, with milk collected during and after infusion. Label recovery in the collected milk depends on several factors. Of course, small amounts of milk protein, and therefore label, are lost during the purification process of the collected milk. However, a more important factor is the efficiency of milk protein synthesis from the infused L- $\left[1-{ }^{13} \mathrm{C}\right]$ phenylalanine in the udder by the cow. The maximal theoretical efficiency of leucine incorporation in milk proteins by the udder is $28 \%$, under conditions where the isotope tracer is infused intra-arterially and all synthesized protein is derived from arterial leucine (Boirie et al., 1995). In contrast, in the present study, L- $\left[1-{ }^{13} \mathrm{C}\right]$ phenylalanine was infused intravenously. Therefore, some label will be lost via AA extraction in other tissues before appearance in the pudic artery. Furthermore, although most AA in the pudic artery will be used for milk protein synthesis, a small fraction will also be incorporated in udder tissue (Oddy et al., 1988). Finally, we continued to collect milk for $24 \mathrm{~h}$ after cessation of label infusion. This approach increases label recovery but does not allow collection of all label incorporated in the milk, which is clearly illustrated in Figure 3, as L- $\left[1-{ }^{13} \mathrm{C}\right]$ phenylalanine enrichment in the collected milk is still substantially elevated $24 \mathrm{~h}$ after cessation of tracer administration (4.3 MPE). With these considerations, label recovery in the milk was $22.1 \%$, similar to previously reported efficiency using labeled leucine (Boirie et al., 1995), which indicates that the applied $\mathrm{L}-\left[1-{ }^{13} \mathrm{C}\right]$ phenylalanine administration dose and infusion regimen was highly effective. As such, we obtained casein and whey protein fractions with $\left[1-{ }^{13} \mathrm{C}\right]$ phenylalanine enrichment of 29.4 MPE following infusion of approximately $200 \mathrm{~g}$ of $\left[1-{ }^{13} \mathrm{C}\right]$ phenylalanine per cow. The latter is much higher than the $\left[1-{ }^{13} \mathrm{C}\right]$ leucine enrichments in milk protein fractions obtained by Boirie et al. (1995), which ranged from 10.5 to 19.4 MPE. Ingestion of such highly labeled dietary protein sources ( $>25 \mathrm{MPE})$ should result in greater plasma tracer enrichments and, as such, allow a more in-depth assessment of the fate of the ingested protein by measuring AA tracer incorporation in skeletal muscle tissue.

To investigate the applicability of the intrinsically labeled dietary protein to study in vivo protein digestion and absorption kinetics and the subsequent muscle protein synthetic response we performed a proof-ofprinciple experiment in humans. Two healthy men were selected to participate in an experimental trial in which they ingested $35 \mathrm{~g}$ of the $\left[1-{ }^{13} \mathrm{C}\right]$ phenylalaninelabeled casein. Immediately after ingestion of the bolus of casein, plasma $\left[1-{ }^{13} \mathrm{C}\right]$ phenylalanine enrichments increased substantially (Figure 4A). Calculation of exogenous phenylalanine appearance rate over the 6-h postprandial period allowed a direct assessment of the percentage of ingested phenylalanine that was taken up by the splanchnic area (i.e., the amount of ingested phenylalanine that did not appear in the circulation). Splanchnic extraction of a single 35-g bolus of casein was shown to be $74 \pm 4 \%$, which is considerably larger than previous estimations based on continuous oral administration of free phenylalanine in healthy, elderly men (47\%; Volpi et al., 1999).

Over the entire 6-h postprandial period, plasma L- $\left[1-{ }^{13} \mathrm{C}\right]$ phenylalanine enrichments averaged $0.08 \pm$ 0.02 (TTR; Figure 4A). The latter has previously been shown to be high enough to allow accurate assessment of the muscle protein synthetic response (Koopman et al., 2005, 2006, 2007a, 2008; Beelen et al., 2008; Manders et al., 2008). In accordance, the net increase in skeletal muscle protein $\mathrm{L}-\left[1-{ }^{13} \mathrm{C}\right]$ phenylalanine enrichment averaged $0.00025 \pm 0.00001$ and resulted in a calculated muscle protein FSR of $0.058 \pm 0.012 \% / \mathrm{h}$. Therefore, the present study shows that dietary protein intrinsically labeled with $\left[1-{ }^{13} \mathrm{C}\right]$ phenylalanine with a high level of enrichment can be effectively used to study dietary 
protein digestion and absorption as well as the subsequent postprandial muscle protein synthetic response in vivo in humans.

Besides the ingestion of a single bolus of L- $\left[1-{ }^{13} \mathrm{C}\right]$ phenylalanine labeled casein, subjects received continuous intravenous infusions with L-[ring- ${ }^{2} \mathrm{H}_{5}$ ]phenylalanine and $\mathrm{L}-\left[1-{ }^{13} \mathrm{C}\right]$ leucine. The continuous infusion with $\mathrm{L}^{-}$ [ring- ${ }^{2} \mathrm{H}_{5}$ ] phenylalanine was included to assess wholebody phenylalanine flux, allowing the calculation of total, exogenous, and endogenous phenylalanine appearance rates. Our calculations showed a clear reduction in endogenous phenylalanine appearance rate following ingestion of a bolus of dietary protein (Figure 4B). Furthermore, continuous infusion of $\mathrm{L}-\left[1-{ }^{13} \mathrm{C}\right]$ leucine was included to assess the protein synthetic response using a continuous, intravenous tracer administration procedure. The net increase in protein-bound $\mathrm{L}-\left[1-{ }^{13} \mathrm{C}\right]$ leucine enrichment averaged $0.00023 \pm 0.00001$ and resulted in calculated skeletal muscle protein FSR of $0.061 \pm 0.001 \% / \mathrm{h}$. Clearly, muscle protein FSR determined from the continuous intravenous L- $\left[1-^{13}\right]$ leucine tracer infusion or the bolus ingestion of the $\mathrm{L}-\left[1{ }^{13} \mathrm{C}\right]$ phenylalanine-labeled protein source were quite similar. In accordance, a strong significant correlation between muscle FSR assessed by continuous intravenous $\mathrm{L}-\left[1-{ }^{13} \mathrm{C}\right]$ leucine infusion or ingestion of a single bolus of L- $\left[1-{ }^{13}\right]$ phenylalanine-enriched casein has recently been observed in our laboratory (Koopman et al., 2009). The strong correlation implies that both methods seem valid to assess the muscle protein synthetic response to dietary protein ingestion in vivo in humans. However, the combined application of ingesting an intrinsically labeled protein source with the continuous, intravenous administration of L- $\left[\right.$ ring- $\left._{-}{ }^{2} \mathrm{H}_{5}\right]$ phenylalanine allows measurement of digestion and absorption kinetics and the subsequent fate of the ingested dietary protein and the effect this has on whole-body and muscle protein metabolism.

We conclude that the production of intrinsically $\mathrm{L}-\left[1-{ }^{13} \mathrm{C}\right]$ phenylalanine-labeled milk protein is feasible and provides dietary protein that can be used to investigate protein digestion and absorption and the subsequent muscle protein synthetic response in vivo in humans. The use of intrinsically labeled protein sources represents a powerful research tool in the field of human nutrition.

\section{ACKNOWLEDGMENTS}

We gratefully acknowledge the expert technical assistance of J. Senden and A. Zorenc (NUTRIM, Maastricht University, Maastricht, the Netherlands). We appreciate the enthusiastic support of all subjects who volunteered to participate in the studies. The au- thors are grateful to P. Lamberton (INRA, UMR1080 Dairy Production, Saint-Gilles, France) and his team members for their helpful assistance including the care, and feeding of cows. YB, RK and LJCvL designed the study; AKK, ALdR, SL, and JF were responsible for the production and preparation of the intrinsically labeled proteins; RK and LJCvL organized and carried out the clinical experiments; and APG performed the stable isotope analyses; RK and LJCvL performed the analysis of the data and wrote the manuscript together; and WHMS provided medical assistance. A. K. Kies and A. L. de Roos are researchers within DSM Food Specialties (Delft, the Netherlands). No author had any financial or personal conflicts of interest.

\section{REFERENCES}

Anthony, J. C., T. G. Anthony, S. R. Kimball, and L. S. Jefferson. 2001. Signaling pathways involved in translational control of protein synthesis in skeletal muscle by leucine. J. Nutr. 131:856S-860S.

Beelen, M., R. Koopman, A. P. Gijsen, H. Vandereyt, A. K. Kies, H. Kuipers, W. H. Saris, and L. J. van Loon. 2008. Protein coingestion stimulates muscle protein synthesis during resistance-type exercise. Am. J. Physiol. Endocrinol. Metab. 295:E70-E77.

Bergstrom, J. 1975. Percutaneous needle biopsy of skeletal muscle in physiological and clinical research. Scand. J. Clin. Lab. Invest. 35:609-616.

Berthold, H. K., D. L. Hachey, P. J. Reeds, O. P. Thomas, S. Hoeksema, and P. D. Klein. 1991. Uniformly ${ }^{13} \mathrm{C}$-labeled algal protein used to determine amino acid essentiality in vivo. Proc. Natl. Acad. Sci. USA 88:8091-8095.

Biolo, G., R. Y. Fleming, S. P. Maggi, and R. R. Wolfe. 1995. Transmembrane transport and intracellular kinetics of amino acids in human skeletal muscle. Am. J. Physiol. 268:E75-E84.

Boirie, Y., M. Dangin, P. Gachon, M. P. Vasson, J. L. Maubois, and B. Beaufrere. 1997a. Slow and fast dietary proteins differently modulate postprandial protein accretion. Proc. Natl. Acad. Sci. USA 94:14930-14935.

Boirie, Y., J. Fauquant, H. Rulquin, J. L. Maubois, and B. Beaufrere. 1995. Production of large amounts of $\left[{ }^{13} \mathrm{C}\right]$ leucine-enriched milk proteins by lactating cows. J. Nutr. 125:92-98.

Boirie, Y., P. Gachon, and B. Beaufrere. 1997b. Splanchnic and wholebody leucine kinetics in young and elderly men. Am. J. Clin. Nutr. 65:489-495.

Boirie, Y., P. Gachon, S. Corny, J. Fauquant, J. L. Maubois, and B. Beaufrere. 1996. Acute postprandial changes in leucine metabolism as assessed with an intrinsically labeled milk protein. Am. J. Physiol. 271:E1083-E1091.

Calbet, J. A., and J. J. Holst. 2004. Gastric emptying, gastric secretion and enterogastrone response after administration of milk proteins or their peptide hydrolysates in humans. Eur. J. Nutr. 43:127139.

Chow, L. S., R. C. Albright, M. L. Bigelow, G. Toffolo, C. Cobelli, and K. S. Nair. 2006. Mechanism of insulin's anabolic effect on muscle: Measurements of muscle protein synthesis and breakdown using aminoacyl-tRNA and other surrogate measures. Am. J. Physiol. Endocrinol. Metab. 291:E729-E736.

Dangin, M., Y. Boirie, C. Garcia-Rodenas, P. Gachon, J. Fauquant, P. Callier, O. Ballevre, and B. Beaufrere. 2001. The digestion rate of protein is an independent regulating factor of postprandial protein retention. Am. J. Physiol. Endocrinol. Metab. 280:E340-E348.

Dangin, M., Y. Boirie, C. Guillet, and B. Beaufrere. 2002. Influence of the protein digestion rate on protein turnover in young and elderly subjects. J. Nutr. 132:3228S-3233S.

Dangin, M., C. Guillet, C. Garcia-Rodenas, P. Gachon, C. BouteloupDemange, K. Reiffers-Magnani, J. Fauquant, O. Ballevre, and B. 
Beaufrere. 2003. The rate of protein digestion affects protein gain differently during aging in humans. J. Physiol. 549:635-644.

Deglaire, A., P. J. Moughan, C. Bos, K. Petzke, S. M. Rutherfurd, and D. Tome. 2008. A casein hydrolysate does not enhance gut endogenous protein flows compared with intact casein when fed to growing rats. J. Nutr. 138:556-561.

Engelen, M. P., N. E. Deutz, R. Mostert, E. F. Wouters, and A. M. Schols. 2003. Response of whole-body protein and urea turnover to exercise differs between patients with chronic obstructive pulmonary disease with and without emphysema. Am. J. Clin. Nutr. 77:868-874.

Evenepoel, P., M. Hiele, A. Luypaerts, B. Geypens, J. Buyse, E. Decuypere, P. Rutgeerts, and Y. Ghoos. 1997. Production of egg proteins, enriched with L-leucine- ${ }^{13} \mathrm{C} 1$, for the study of protein assimilation in humans using the breath test technique. J. Nutr. 127:327-331.

Floyd, J. C. Jr., S. S. Fajans, J. W. Conn, R. F. Knopf, and J. Rull. 1966. Stimulation of insulin secretion by amino acids. J. Clin. Invest. 45:1487-1502.

Husek, P. 1991. Amino acid derivatization and analysis in five minutes. FEBS Lett. 280:354-356.

Hutchens, T. W., J. F. Henry, T. T. Yip, D. L. Hachey, R. J. Schanler, K. J. Motil, and C. Garza. 1991. Origin of intact lactoferrin and its DNA-binding fragments found in the urine of human milkfed preterm infants. Evaluation by stable isotopic enrichment. Pediatr. Res. 29:243-250.

Irving, C. S., E. W. Malphus, M. R. Thomas, L. Marks, and P. D. Klein. 1988. Infused and ingested labeled lysines: Appearance in human-milk proteins. Am. J. Clin. Nutr. 47:49-52.

Kimball, S. R., P. A. Farrell, and L. S. Jefferson. 2002. Invited Review: Role of insulin in translational control of protein synthesis in skeletal muscle by amino acids or exercise. J. Appl. Physiol. 93:1168-1180.

Koopman, R., M. Beelen, T. Stellingwerff, B. Pennings, W. H. Saris, A. K. Kies, H. Kuipers, and L. J. van Loon. 2007a. Co-ingestion of carbohydrate with protein does not further augment post-exercise muscle protein synthesis. Am. J. Physiol. Endocrinol. Metab. 293:E833-E842.

Koopman, R., N. Crombach, A. P. Gijsen, S. Walrand, J. Fauquant, A. K. Kies, S. Lemosquet, W. H. Saris, Y. Boirie, and L. J. van Loon. 2009. Ingestion of a protein hydrolysate is accompanied by an accelerated in vivo digestion and absorption rate when compared with its intact protein. Am. J. Clin. Nutr. 90:106-115.

Koopman, R., D. L. Pannemans, A. E. Jeukendrup, A. Gijsen, J. M. G. Senden, D. Halliday, W. H. M. Saris, L. J. C. van Loon, and A. J. M. Wagenmakers. 2004. The combined ingestion of protein and carbohydrate improves protein balance during ultra endurance exercise. Am. J. Physiol. Endocrinol. Metab. 287:E712-E720.

Koopman, R., W. H. Saris, A. J. Wagenmakers, and L. J. van Loon. 2007b. Nutritional interventions to promote post-exercise muscle protein synthesis. Sports Med. 37:895-906.
Koopman, R., L. B. Verdijk, M. Beelen, M. Gorselink, A. N. Kruseman, A. J. Wagenmakers, H. Kuipers, and L. J. van Loon. 2008. Coingestion of leucine with protein does not further augment postexercise muscle protein synthesis rates in elderly men. Br. J. Nutr. 99:571-580.

Koopman, R., L. B. Verdijk, R. J. F. Manders, A. P. Gijsen, M. Gorselink, E. Pijpers, A. J. M. Wagenmakers, and L. J. C. van Loon. 2006. Co-ingestion of protein and leucine stimulates muscle protein synthesis rates to the same extent in young and elderly lean men. Am. J. Clin. Nutr. 84:623-632.

Koopman, R., A. J. Wagenmakers, R. J. Manders, A. H. Zorenc, J. M. Senden, M. Gorselink, H. A. Keizer, and L. J. van Loon. 2005. Combined ingestion of protein and free leucine with carbohydrate increases postexercise muscle protein synthesis in vivo in male subjects. Am. J. Physiol. Endocrinol. Metab. 288:E645-E653.

Manders, R. J., R. Koopman, M. Beelen, A. P. Gijsen, W. K. Wodzig, W. H. Saris, and L. J. van Loon. 2008. The muscle protein synthetic response to carbohydrate and protein ingestion is not impaired in men with longstanding type 2 diabetes. J. Nutr. 138:1079-1085.

Oddy, V. H., D. B. Lindsay, and I. R. Fleet. 1988. Protein synthesis and degradation in the mammary gland of lactating goats. J. Dairy Res. 55:143-154.

Proud, C. G. 2004. mTOR-mediated regulation of translation factors by amino acids. Biochem. Biophys. Res. Commun. 313:429-436.

van Loon, L. J., M. Kruijshoop, P. P. Menheere, A. J. Wagenmakers, W. H. Saris, and H. A. Keizer. 2003. Amino acid ingestion strongly enhances insulin secretion in patients with long-term type 2 diabetes. Diabetes Care 26:625-630.

van Loon, L. J., M. Kruijshoop, H. Verhagen, W. H. Saris, and A. J. Wagenmakers. 2000. Ingestion of protein hydrolysate and amino acid-carbohydrate mixtures increases postexercise plasma insulin responses in men. J. Nutr. 130:2508-2513.

Volpi, E., H. Kobayashi, M. Sheffield-Moore, B. Mittendorfer, and R. R. Wolfe. 2003. Essential amino acids are primarily responsible for the amino acid stimulation of muscle protein anabolism in healthy elderly adults. Am. J. Clin. Nutr. 78:250-258.

Volpi, E., B. Mittendorfer, S. E. Wolf, and R. R. Wolfe. 1999. Oral amino acids stimulate muscle protein anabolism in the elderly despite higher first-pass splanchnic extraction. Am. J. Physiol. 277:E513-E520.

Wagenmakers, A. J. 1999. Tracers to investigate protein and amino acid metabolism in human subjects. Proc. Nutr. Soc. 58:9871000 .

Wolfe, R. R. 1992. Radioactive and Stable Isotope Tracers in Biomedicine: Principles and Practice of Kinetic Analysis. WileyLiss, New York, NY.

Wolfe, R. R. 2002. Regulation of muscle protein by amino acids. J. Nutr. 132:3219S-3224S 